\title{
Petrol Kirliliği Kaynakı Uluslararası Tazminat Sistemi ve Mesuliyetin Paylaştırılması
}

\author{
Bünyamin KAMAL* Erhan ÇİLOĞLU \\ Recep Tayyip Erdoğan Üniversitesi, Turgut Kıran Denizcilik Fakültesi, 53900 Rize, Türkiye
}

Atıf yapmak için: Kamal, B. \& Çiloğlu, E. (2020). Petrol Kirliliği Kaynaklı Uluslararası Tazminat Sistemi ve Mesuliyetin Paylaştırılması. Anadolu Çev. ve Hay. Dergisi, 5(2), 161-172.

How to cite: Kamal, B. \& Çiloğlu, E. (2020). Petrol Pollution Sourced International Compensation System and Distribution of Liability. J. Anatolian Env. and Anim. Sciences, 5(2), 161-172.

: https://orcid.org/0000-0002-9885-114X D: https://orcid.org/0000-0002-9995-0377
Öz: Dünya enerji ihtiyacının ciddi bir kısmı petrolden tedarik edilmektedir. Farklı ulaştırma modlarıyla taşınsa da petrol ticareti için düşük maliyetli olduğu için en çok deniz ulaştırma modu kullanılmaktadır. Denizlerdeki yoğun petrol taşımacıllğ kaynaklanan kazalar sadece kıyı devletlerindeki yapıları değil kirlenen alanlardaki insanların yaşamlarını da etkilemektedir. Bu sebebe binaen petrol kirliliğinden zarar görenlerin tazmin edilmesi bir gereklilik olarak ortaya çıkmaktadır. Tanker gemileri kaynaklı petrol kirliliği mağdurlarının tazmin edilmesi için bazı çabalar gösterilmiştir. Bu bağlamda 1969 Hukuki Sorumluluk Sözleșmesi (CLC 1992) ve 1971 Fon Sözleşmesi (Fon 1971) geliştirilmiştir ve bunlar sonradan CLC 1992 ve Fon 1992 Sözleşmeleri ile ve son olarak üçüncü kademe tazminat sistemini teşkil eden Ek Fon Protokolü ile ikame edilmiştir. Bu düzenlemelerde, mesuliyet yükünün çoğunluğu Petrol Kirliliği Tazminat (IOPC) Fonlarına (1992 Fonu ve Ek Fon) katkıda bulunan petrol ithal eden şirketlerin omuzuna yüklenmiștir ve bu petrol ithal eden şirketler ve tanker gemisi malikleri arasında açık bir eşitsizliğe yol açmıştır. Bundan dolayı, petrol ithal eden șirketler lehine, gemi malikleri adına Uluslararası P\&I Kulüpler Grubu gönüllü olarak STOPIA ve TOPIA adlı iki mekanizma geliştirmiştir. Bu çalışmada üç basamaklı tazminat sistemi, STOPIA ve TOPIA mekanizmaları analiz edilmiștir. STOPIA ve TOPIA'nın ilk on yıllık gözden geçirme periyodu mesuliyetin dağıtılması hususunda değerlendirilmiştir ve görülmektedir ki gelinen durum itibari ile tanker malikleri ile petrol alıcıları arasında mesuliyetin paylaştırılması hususunda bir dengeye ulaşıldığı görülmektedir.

\section{Petrol Pollution Sourced International Compensation System and Distribution of Liability}

*Corresponding author's: Bünyamin KAMAL

Recep Tayyip Erdoğan University, Turgut Kuran Maritime of Faculty, 53900 Rize, Türkiye.

凶: bunyamin.kamal@erdogan.edu.tr Cep telefonu : +90 (507) 4409675 Faks $\quad:+90(464) 3111072$
Abstract: A significant part of the world's energy need are supplied from oil. Although it is transported with different modes of transportation, marine transportation mode is the most used for oil trade due to it's low cost. Intense oil transportation in the seas triggers environmental risks and accidents stemming from oil tankers affect not only marine environment but also structures in the coastal states and people living in the polluted areas. For this reason, compensation of those who suffer from this oil pollution becomes a necessity. There have been some efforts to compensate the victims of tanker vessel sourced oil pollution. In this context, 1969 Civil Liability Convention and 1971 Fund Convention was developed and later on these were replaced with 1992 Civil Liability Convention, 1992 Fund Convention and finally Supplementary Protocol 2003 constituting third-tier compensation system. In these regulations, majority of the liability burden was put on the shoulder of the petrol importing companies by contributing to IOPC Funds (Fund 92 and Supplementary Fund) and this led to an apparent inequality between shipowners and petrol importing companies. Due to this, on behalf of the shipowners, International Group of P\&I Clubs voluntarily developed two mechanisms called STOPIA and TOPIA in order to balance this situation for petrol receiving companies' favor. In this study, third tier compensation scheme, STOPIA and TOPIA mechanisms have been analyzed. First annual review of STOPIA and TOPIA has ben evaluated with regard to liability distribution and it seems that a balance has been reached so far between tanker owners and petrol receivers regarding sharing of liability.

Keywords: CLC 92, fund 92, oil pollution compensation, STOPIA, TOPIA 


\section{GíRiș}

1967 yılında vuku bulan ve büyük çaplı kirlenmeye neden olan Torrey Canyon kazası akabinde ortaya çıkan tablonun neticesi olarak uluslararası alanda petrol kirliliğinden zarar gören tarafların tazmin edilmesi meselesi hususunda düzenleme ihtiyacı ortaya çıkmıştır. Bu bağlamda o dönem ismi IMCO olan uluslararası denizcilik örgütü tarafından (IMO) Hukuki Sorumluluk Sözleşmesi (CLC 69) şekillendirilmiştir (Küçükyıldız, 2014). Bu sözleşme ile petrol kirliliğinden zarar görenlerin mağduriyet miktarlarını tazmin etmesi için donatanlar mesul tutulmuştur ve paralel olarak donatanın mali gücünü teminat altına alabilmek için zorunlu sigorta yaptırması da öngörülmüştür (Acar, 2009).

CLC 69 sözleşmesi petrol kirliliği kaynaklı zarar görenlerin tazmin edilebilmesi için ciddi bir girişim olsa da bu sözleşme daha yürürlüğe girmeden mahkemelerin yetki sınırlarının tespiti, zararların ödenmesi ile alakalı hususların yeteri kadar netleştirilemediği ortaya çıkmıştır. Ayrıca IMO konferanslarında bazı ülke temsilcileri tarafindan donatanların öngöremediği durumlar karşısında doğrudan mesul tutulmaları kabul görmemekle beraber bazı ülke temsilcileri de donatanların mesuliyet limitlerinin daha da arttırılması gerektiğini savunmuşlardır. $\mathrm{Bu}$ durum açıkça taşıtan pozisyonunda olan ülkeler ile daha çok taşıyan tarafında olan ülkelerin menfaatlerinin dengede olmamasından kaynaklı olarak Hukuki Sorumluluk Sözleşmesinin tadil edilmesi ihtiyacı hâsıl olmuştur (Küçükyıldız, 2014).

Deniz taşımacılığı endüstrisini ağır sorumluluk altına sokan bu sorumluluk rejimini takiben 1971 Fon Sözleşmesi (Fund 71) şekillendirilmiştir. Fon Sözleşmesi vesilesi ile petrol kirliliğinden zarar gören tarafların tazmin edilmesi hususunda tamamlayıcı bir fonksiyon icra edecek olan bir fon (71 Fonu) kurulması kararlaştırılmıştır. Bu fona yapılacak olan katkıların petrol ithal eden şirketler tarafindan finanse edilmesi öngörülmüştür. CLC 69 ve Fon 71 Sözleşmeleri bağlamında petrol kirliliği mağdurlarının yükünün donatanlar ve petrol ithal eden şirketler arasında eşit olarak dağıtılması öngörülerek, 2 basamaklı bir sorumluluk sistemi teşkil edilmiştir (Acar, 2009). Böylece bir petrol kirliliği olayında hâsıl olan tazminat taleplerinden evvela geminin maliki mesul iken, malikin mesuliyetini aşan tazminat taleplerinin ortaya çıkması halinde 71 Fon Sözleşmesi bağlamında kurulan Uluslararası Petrol Kirliliği Tazmin Fonu (IOPC Fund) devreye girmektedir (Küçükyıldız, 2014). Ayrıca sözleşmelere taraf devlet sayısının artmasıyla paylaşılması gereken yükün o denli azalacağ1 düşünülmüştür (Acar, 2009).

1978 y1lında meydana gelen Amaco Cadiz kazasında Uluslararası Fon'nun yeterli olmadığı ortaya çıkmış ve mesuliyet üst sınırlarının yükseltilmesi hususu gündeme gelmiştir. Buna paralel olarak 1984 yılında CLC
69 ve Fon 1971 Sözleşmeleri için yeni protokoller kabul edilmiş ve bu vesile ile mesuliyet üst sınırları yukarı çekilmiştir. Fakat protokoller yürürlüğe girme açısından başarısız olmuştur zira daha çok taşıtan ülke pozisyonunda olan ve kirlilik tazmini fonuna en çok katkıda bulunan ABD protokollerle mesuliyet miktarlarının yükseltilmesine itiraz etmiş ve donatanların sınırlı mesuliyet yerine sınırsız mesuliyetini savunmuştur. Ayrıca fona en çok katkı yapan devletlerden biri olan Japonya da katkı miktarının çok fazla artacağı çekincesiyle Protokolleri onaylamayacağını deklare etmiştir (Abdullayev, 2003). Böylece protokoller yürürlüğe girmemiş ve ABD uluslararası tazmin sisteminden ayrılıp kendi Petrol Kirliliği Yasasını (OPA 90) çıkartarak yeni bir rejim ortaya koymuştur (Küçükyıldız, 2014). Burada ABD'nin uluslararası fondan tamamen ayrılmasını ve kendi tazmin mekanizmasını kurması hususunu tetikleyen olay ise yaşadığı en büyük kazalardan biri olan ve 1989 yılında meydana gelen Exxon Valdez kazasıdır (Abdullayev, 2003).

1991 yılında meydana gelen Haven kazası ile tazminat rejiminde tereddütsüz yenilik yapılması fikri benimsenmekle beraber ABD'nin katılımı olmadan 1992 protokolleri kabul edilmiştir. Burada aslında 1984 Protokollerinde yükseltilen mesuliyet miktarları değiştirilmemiş fakat yürürlüğe girme koşullarında değişikliğe gidilmiş ve böylece protokoller 1996 yılında yürürlüğe girmiştir (Abdullayev, 2003). Bu yeni protokollerle 16 Mayıs 1998 tarihinden itibaren yeni rejim olarak sayılan 1992 Protokollerine akit olan devletler CLC 69 ve Fon 71 Sözleşmelerinden ayrılmış sayılmıştır ve feshedilen bu sözleşmelerin yerine getirilen protokoller Hukuki Sorumluluk Sözleşmesi (CLC 1992) ve 1992 Fon Sözleşmesi (FUND 1992) olarak anılmaktadır (Küçükyıldız, 2014).

Petrol kirliliği kaynaklı tazminat miktarlarının artmasına binaen 2005 yılında Ek Fon Protokolü 2003 devreye girmiştir. Burada tazminat mesuliyetinin ciddi bir kısmını üstlenen petrol alıcılarının yükünü dengeleme adına 2006 yılında STOPIA ve TOPIA mekanizmaları devreye alınmıştır. $\mathrm{Bu}$ çalışmada belirtilen hususlar sırasıyla incelenmiştir ve aradan geçen süre boyunca tazminat mesuliyetlerinin taraflar arasinda dengelenmesi hususunda arzu edilen gayeye ulaşılıp ulaşılmadığının tespiti amacına binaen STOPIA ile TOPIA sonrası dönem ve gözden geçirme periyodu ayrıntılı olarak değerlendirilmiştir.

\section{Hukuki Sorumluluk Sözleşmesi (CLC 1992) ve} 1992 Fon Sözleşmesi (FUND 1992): 1992 Hukuki Sorumluluk Sözleşmesi ve 1992 Fon Sözleşmelerinin temel gayesi uluslararası düzeyde petrol kirlenmesinden mağdur olanların zararlarının mümkün mertebe mahkemelere gidilmeksizin ve bütün alacaklı olanlara adil davranılarak hızlı bir şekilde tazmin edilmelerini temin etmektir. Bu bağlamda kirlilik mağdurları için CLC 92 birinci kademe 
güvenceyi ve 92 Fon Sözleşmesi ikinci kademe güvenceyi teşkil etmektedir (Demir, 2012). Petrol kirliliği karşısında zarar gören tarafların tazmin miktarları evvela CLC 92 bağlamında hususen bu sözleşmeye binaen zorunlu hale getirilen sigortadan karşılanmaktadır. Mesuliyet miktarlarının CLC 92'de yer alan limitleri aşması ve bu sözleşme hükümlerine göre tazmin edilememesi durumunda Fon 1992 Sözleşmesi devreye girerek belirtilen sinırlar dâhilinde kirlilik mağdurlarına tazminat ödemesi yapılmaktadır (Demir, 2012).

1992 yilında getirilen Protokollerle dizayn edilen yeni sistemde Fon Sözleşmesi ve Sorumluluk arasındaki ilişki dikkate alınarak olay, gemi, gemi maliki, petrol, şahıs, koruma tedbirleri gibi kavramlar her iki sözleşmede de aynı manaya gelecek şekilde düzenlenmiştir (Abdullayev, 2003).

30 Mayıs 1996 yılında yürürlüğe giren bu sözleşmeler dünya çapında kabul görmüş ve denize kıyısı olan bütün $\mathrm{AB}$ ülkeleri bu sözleşmelere taraf olmuştur. Türkiye ise bu sözleşmelere Avrupa Birliği uyum bağlamında 9/5/2001 tarihinde taraf olmuştur ve 24397 sayılı Resmi Gazete'de yayınlanarak yürürlüğe girmiştir (Demir, 2012).

\subsection{Hukuki Sorumluluk Sözleșmesi (CLC 1992):}

1992 Hukuki Sorumluluk Sözleşmesi 2 no'lu madde de belirtildiği üzere (a) akit devletlerden birinin karasuları da dâhil olmak üzere kendi ülkesinde, uluslararası hukuka göre belirlenmiş veyahut tespit edilmemiş ise bu devlet tarafindan uluslararası hukuk temeline göre belirlenmiş münhasır ekonomik bölgesinde veyahut bitişik bölgesindeki sebep olunan kirlilik zararına (b) nerede alındığına bakılmaksızın böyle bir zararı minimize etmek veya önlemek için alınan önleyici tedbirlere uygulanmaktadır (IOPC, 2011).

CLC 92 ile donatanın mesuliyet sinırları genişletilmiş ve belirli bir meblağ ile sınırlandırılabilir. Sözleşmenin 5. Maddesinde belirtildiği üzere, 5000 tonaj birimini geçmeyen gemiler için 3 milyon Özel Çekme Hakkı (SDR) ile daha tonajlı gemiler için bu meblağa ton başına 420 SDR eklenerek gemi malikinin mesuliyeti sınırlanabilir. Öte yandan malikin mesuliyeti hiçbir halde 59.7 milyon SDR'yi geçemez. Bu sınırlama hakkından istifade etmek isteyen gemi malikinin CLC 92 Sözleşmesine taraf olan ve konvansiyonun hükümlerine göre yetkisi bulunan bir devlet mahkemesinde bir sinırlama fonu kurması gerekmektedir (Acar, 2009).

$\mathrm{Bu}$ sınırlar artış gösteren kazalar ve yaşanan tecrübeler doğrultusunda 2000 y1lında zımni kabul (tacit acceptance) yöntemiyle değiştirilmiş ve 1 Kasım 2003 tarihinde bu değişiklik yürürlüğe girmiştir. Yapılan bu değişiklik ile mesuliyet miktarları \% 50.37 oranında yükseltilmiş ve 5000 grostonu aşmayan gemiler için 4.51 milyon SDR olurken 5000 ile 140.000 groston arasındaki her bir gemi için 3 milyon SDR'ye ilave olarak her bir ek tonaj için 631 SDR ve 140.000 grostonu aşan gemiler için 89.77 milyon SDR olarak güncellenmiş̧ir. Öte yandan hâsıl olan kirliliğin malik tarafindan zarar vermek kastıyla veyahut muhtemelen zarara sebebiyet verebileceğini bilerek ve dikkatsizce malikin yaptığ ihmalinden kaynaklandığının ispatı durumunda, geminin maliki mesuliyetini sınırlama hakkından istifade edemeyecektir. Ayrıca belirtilmelidir ki CLC 69 Sözleşmesinde gemilerin net tonu hesaba katılırken CLC 92'de gemilerin grostonu hesaba katılmaktadır. Eğer ki kirliliğin oluşmasında malikin kusuru olmasa bile, malik kendi gemisinden sızan veya dökülen petrolün sebep olduğu zararların tazmini için ödeme yapmakla mesuldür (Küçükyıldız, 2014).

Öte yandan ispat yükümlülüğü gemi malikine ait olmak üzere, sınırlı olarak bazı durumlarda malike mesuliyetten kurtulma imkânı verilmiştir. Aşağıda belirtilen kirlenme zararları için gemi malikinin hiçbir mesuliyeti yoktur.

a) Savaş, iç savaş, ayaklanma, beklenmeyen ve önlenemeyen tabiat hadiselerinde,

b) Zararın tamamen bir üçüncü şahsın zarara sebebiyet verme niyetiyle yaptı̆̆ bir hareket veyahut hareketsizliğin sonucu ise,

c) İlgili devletin seyir yardımcıları ve fenerlerin bakım-tutum görevindeki bir ihmalin veyahut başka yanlış hareketinin sonucu ise.

Ayrıca, gemi maliki zarar gören tarafin kasıtlı olarak ve bilerek bu zarara tamamen veyahut kısmen fiillerinin veyahut ihmalinin sebep olduğunu ispatlaması durumunda, gemi maliki zarar gören tarafa karşı sorumluluktan tamamen veyahut kısmen kurtulabilecektir (Acar, 2009).

1.1.1. Zorunlu Sigorta: CLC 92 madde 7 (1)'de belirtildiği üzere sözleşmeye akit bir devletin siciline kayıtlı ve 2000 tondan fazla petrolü kargo olarak taşıyan bir geminin maliki bu konvansiyonun madde 5 (1)'de belirtilen mesuliyet miktarını karşılacak miktarda sigortaya sahip olmak zorunda veyahut banka garantisi/uluslararası tazminat fonu tarafindan sağlanan sertifika gibi diğer finansal güvenceyi bulundurmakla mükelleftir (IOPC, 2011). Buna binaen sözleşmeye taraf devletler kendi sicillerine kayıtlı gemiler için belirtilen sigortaya sahip olan veyahut finansal güvenceyi sunan gemiler için CLC sertifikaları düzenlerler ve kendi sularına giriş-çıkış yapan gemilerin de böyle bir güvenceye sahip olup olmadıklarını denetlerler. Zira sözleşmeye akit bir devletin siciline tescil edilmiş olan ve 2000 ton üzeri petrol yükü taşıyan bir geminin aktif bir P\&I sigortasını gösteren CLC sertifikası yoksa o taraf devletçe bu geminin ticaretine izin verilmez.

Zorunlu sigortanın birçok faydası vardır. Örneğin zorunlu sigorta ihmalkâr bir gemi malikinin tek gemilik şirket (one ship company) teşkil ederek şirketin mal 
varlıklarının değerini düşük tutarak mesuliyetten kaçmasını önlemektedir (Billah, 2011).

Tanker kazaları sonucu hâsıl olan tazminat taleplerinin büyük çoğunluğu IOPC Fonu'nun dahli olmadan IG kulüpleri tarafından elleçlenmektedir. Toplam tanker tonajının yaklaşık \% 90’ını sigortalayan 13 büyük Koruma ve Tazminat Kulübünün (P\&I Kulüp) oluşturduğu Uluslararası Koruma ve Tazminat Kulüpleri Grubu (IG) bünyesindeki kulüpler müşterileri olan gemi maliklerine sunduğu mavi kart (blue card) vesilesi ile hasar tazminat talebinde bulunanların taleplerini teminat altına almakta ve bu bağlamda IG kulüpleri yıllık yaklaşık olarak 7000 mavi kart (blue card) hazırlamaktadır (Oil spills India, 2018). Bu hususta dikkat edilmesi gereken bir husus ise CLC 92 madde 7 (2) (e) fikrasında belirtildiği üzere sertifikanın geçerlilik periyodu sigorta veyahut banka teminat mektubunun geçerlilik tarihinden uzun olmamalıdır (IOPC, 2011).

1.1. 1992 Fon Sözleşmesi (FUND 1992): 1992 Fon Sözleşmesi ile CLC 92'nin yetersiz kaldığı çapta meydana gelen kirlilik zararlarının tazmin edilmesi amaçlanmaktadır ve uygulama alanı CLC 92 Sözleşmesi ile aynıdır. Fon Sözleşmesine göre herhangi bir akit devlette bir y1l içerisinde toplamda 150.000 tondan fazla petrol ithal eden şahısların Fon'a katkıda bulunması gerekmektedir ve burada "şahıs" terimi netliğe kavuşturulmuş ve ortaklıkların veyahut yardımcı şirketlerin de şahıs olduğu özellikle belirtilmiştir. Zira bu vesile ile taraf devletteki tek bir şirketin farklı farklı isimler adı altında faaliyette bulunarak katkıda bulunması gereken asgari tonajı geçmeme girişiminin de önüne geçilmiş olmaktadır (Küçükyıldız, 2014). Fon Sözleşmesine akit bir devletteki petrol alıcısı olan petrol şirketlerinin aldığı petrol miktarları şirket başına belirtilen miktara ulaşmasa bile bu devlet herhangi bir kirlilik durumundan Fon'dan tazminat almaya devam edecektir. Bu bağlamda 2009 yılında Fon Sözleşmesine taraf olan 104 devletten 25 tanesi Fona herhangi bir katkıda bulunmamış iken 2017 yılında 42 taraf devletten katkı petrolü alınamamıştır (IOPC, 2018b; Billah, 2011). Bu ülkeler genel olarak nispeten ekonomisi küçük gelişmekte olan ülkelerdir.

Fon Sözleşmesi aşağıda belirtilen hallerden biri sebebiyle tazmin edilememiş zararların tazminini öngörmektedir.

a) Gemi maliki CLC 92 Sözleşmesindeki mesuliyetten kurtulma sebeplerinden istifade etmişse veya

b) Gemi maliki CLC 92 bağlamında tazmin etmesi gereken miktarı ifa etmede mali açıdan yetersiz ise veyahut kulüp sigortası tazminat taleplerini kapsamamakta ya da yetersiz ise, veya

c) Kirlenme zararından hâsıl olan tazminat meblağı malikin CLC 92'deki sınırlı mesuliyet limitlerini aşıyorsa Fon Sözleşmesi bağlamında kurulan Fon devreye girmektedir.
Öte yandan kirlenme zararı Fon 1992 Sözleşmesi'ne taraf olmayan bir devlette vuku bulmuşsa veyahut tazminat talebinde bulunan taraf kirlenme zararının bir veyahut birden fazla geminin karıştığ 1 bir olayın neticesi olduğunu ispatlayamaz ise Fon ödeme yapmamaktadır. Ayrıca Fon bir savaş, iç savaş, ayaklanma sonucu veya bir savaş gemisi ya da ticaret gemisi olmayan bir devlet gemisinden sızan petrolün kirlenme zararına sebep olduğunu ispatlarsa tazminat ödemesi yapmaktan kurtulur. Buna ek olarak, kirlenme hadisesinden zarar gören tarafin kendi kusuruyla zarara katkıda bulunması durumunda CLC 92'de olduğu gibi Fon'un da bu tarafa karşı sorumluluktan kurtulma imkânı mevcuttur (Acar, 2009).

CLC 92 ile Fon 92 Sözleşmeleri kargo olarak petrol taşımak için inşa edilmiş veyahut sonradan buna dönüştürülmüş bir tanker gemisinden dökülen ve kalıcı kirliliğe sebebiyet veren petrol minerallerinin (persistent oil) dâhil olduğu olayları kapsamaktadır. Kalıcı kirliliğe sebep olan petrol türevi çeşitleri olarak ham petrol, fuel oil, ağır dizel yağı, gres yağı gibi yavaş dağılan ve temizleme gerektiren petrol mineralleri belirtilebilir. Belirtilmelidir ki kerosene, gazolin ve hafif dizel yağı gibi dayanıklı olmayan petrol mineralleri dökülmesine binaen oluşan zararlar sözleşmeler kapsamında tazmin edilmez. Zira bunlar döküldüğü zaman hızlıca buharlaşır ve temizleme faaliyeti gerektirmezler (Keçeli vd., 2013; Küçükyıldız, 2014).

Diğer taraftan bu belirtilen kalıcı kirliliğe sebebiyet veren petrol mineralleri dolayısıyla IOPC Fon'u tarafindan kirlenme zararı (a) petrolün gemiden kaçması veyahut boşaltılmasının sonucu oluşan hasarlar (b) önleyici tedbirlerin maliyetleri ve önleyici tedbirlerin sebebiyet verdiği hasarlar olarak belirtilmektedir. Buna paralel olarak IOPC Fonlarının bugüne kadar kabul edilebilir gördüğü en mühim kirlilik zararları olarak mülkiyet zararları, zarara bağlı kayıp, saf ekonomik kayıp ve çevre zararları ile kirlilik zararını olay olduktan sonra önlemeye matuf veyahut etkisini minimize etmeye yönelik herhangi biri tarafindan alınan makul bir tedbirler belirtilebilir. Burada mülkiyet zararlarından kasıt petrol bulaşan balıkçı ağları, yatlar veyahut iskelelerin temizlik, tamir veyahut yenilenme maliyetleri ifade edilmekte iken zarara bağlı kayıp ise petrolün kirlettiği mülkü temizlenene kadar maruz kaldığı kazanç kaybı olarak ifade edilmektedir. Saf ekonomik kayıp olarak ise eğer ki kirlilik olmasaydı umulan kazancı kaybı olarak ifade edilmektedir ve müşteri kaybeden otelin, plajın veyahut restoranın sahipleri ile tekneleri ve ağlarına petrol bulaşmasa bile balıkların kaçması sonucu avlanamayan balıkçıların maruz kaldığı kazanç kaybı bu bağlamda değerlendirilir. Çevre zararları bağlamında kabul edilebilir bulunan hasar tazminat talepleri olarak tahrip olan çevrenin eski haline getirilmesi için alınan önlemlerin bedelleri bağlamında sunulan talepler belirtilebilir (Acar, 2009) 
Fon 92 Sözleşmesine göre Fon tarafindan kaza başına tazminat talepleri için ödenecek meblağ 135 milyon SDR'dir ve buna gemi malikinin CLC 92 bağlamında ödemesi gereken meblağ dâhildir. Bu bağlamda Fon'un mesul tutulduğu miktar hesaplanırken donatanın veyahut onun adına P\&I kulübünün ödediği miktar 135 milyon SDR'den düşülür. Öte yandan belirtilmelidir ki istisnai olarak Fon'a katkıda bulunan 3 taraf devletin ülkesinde bir önceki yıl ilgili şahıslar tarafından yıllık petrol ithalatı 600 milyon tona eşit ya da üzerine çıkması durumunda 135 milyon SDR olan tazminat üst sınırı 200 milyon SDR'ye çıkartılmıştır (Küçükyıldız, 2014) .
CLC 92'de olduğu gibi 10 Ekim 2000 tarihinde kabul edilen ve 1 Kasım 2003 tarihinde yürürlüğe giren Protokol ile Fon'un sağladığı tazminat üst sınırı \% 50.37 oranında yükseltilmiştir. $\mathrm{Bu}$ durumda Fon tarafından ödenecek tazminat üst sinırı 203 milyon SDR'ye yükseltilmiştir. Fon'a katkı yapan 3 taraf devletteki şahısların yıllık 600 milyon ton üzeri petrol alımı durumunda ise belirtilen üst sınır yaklaşı 300 milyon SDR'ye yükseltilmiştir.

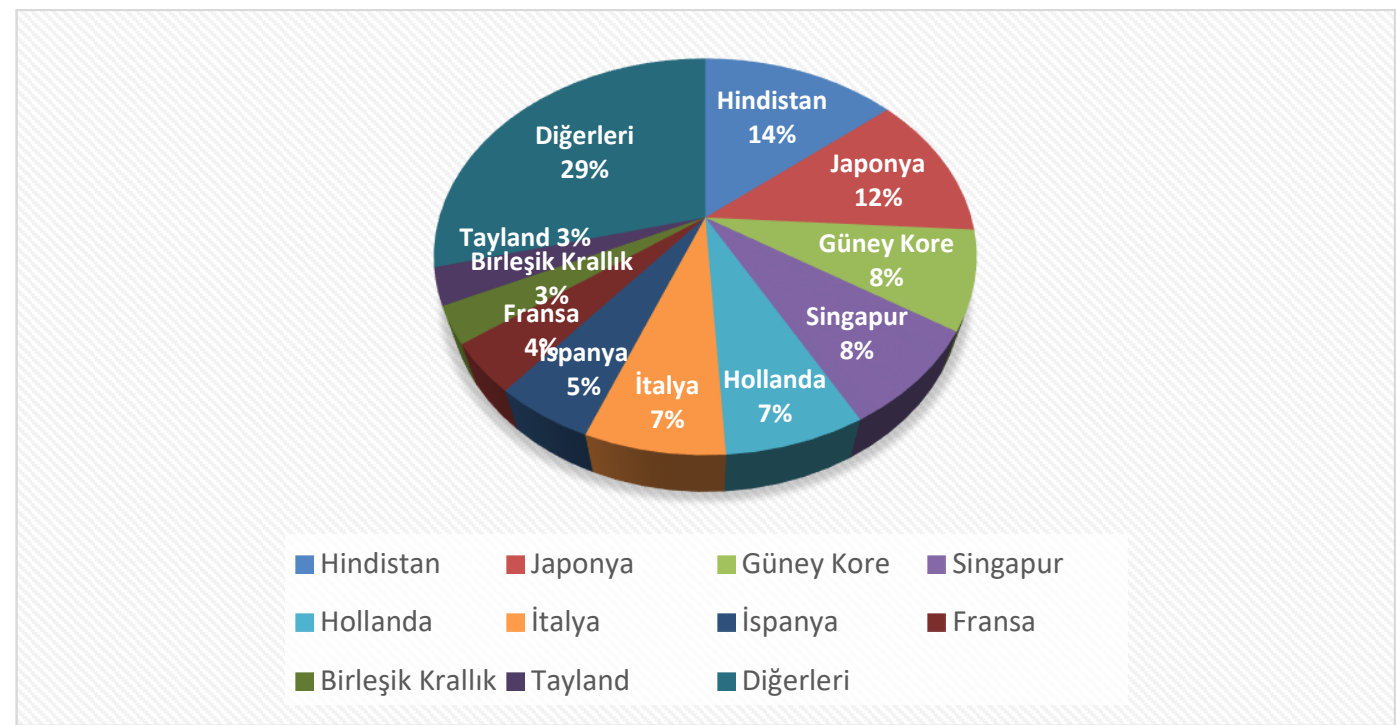

Şekil 1. 2017 Yılında 1992 Fonu Tarafından Üye Devletlerden Alınan Katkı Petrolü (IOPC, 2018(b)).

Figure 1. Contributing Oil Received in 2017 by Member States of 1992 Fund (IOPC, 2018(b)).

IOPC Fon verilerine göre 2020 y1lı itibariyle Fon Sözleşmesi'ne taraf devlet sayısı Türkiye dâhil 115'dir (IOPC, 2020). Normal şartlarda CLC 92'ye taraf olan bir devlet 1992 Fon Sözleşmesine de taraf olmaktadır fakat belirtilmelidir ki böyle bir zorunlulukları yoktur ve 2009 rakamlarına göre 18 devlet CLC 92' taraf olup 92 Fon Sözleşmesi'ne taraf olmamıştır (Acar, 2009). IOPC Fonu 2018 yıllık raporuna göre kuruluş tarihi olan 1978 Ekim ayından itibaren IOPC Fonları 150 petrol kazası olayına müdahil olmuştur. Devreye girdiği 1978 yılından beri IOPC Fonları petrol kirliliği mağdurlarına 684 milyon pound ödeme yapmıştır ve bu miktarın 331 milyon poundluk kısmı 1971 Fon'u bağlamında yapılmıştır (IOPC, 2018(b)). Aşağıdaki Şekil 1'de görüldüğü üzere 2017 yılı rakamlarına göre 1992 Fon'una en çok katkıda bulunan devlet \% 14'lük bir yüzde ile Hindistan'dır ve bunu Japonya ve Güney Kore takip etmektedir ve paralel olarak devletlerin Fon'a katkıda bulundukları petrol miktarları Tablo 1'de gösterilmektedir.
Tablo 1. Taraf Devletlerin 2017 Yılında Katkıda Bulundukları Katk1 Petrolü*

Table 1. Amount of Contributing Oil by Member States in $2017^{*}$

\begin{tabular}{lcc}
\hline Üye Devlet & $\begin{array}{c}\text { 2017 Yllında Alınan Katk1 } \\
\text { Petrolü Miktarı (ton) }\end{array}$ & Yüzdesi \\
\hline Hindistan & 218.709 .791 & $13.84 \%$ \\
Japonya & 196.693 .667 & $12.45 \%$ \\
Güney Kore & 132.489 .698 & $8.39 \%$ \\
Singapur & 122.208 .460 & $7.74 \%$ \\
İtalya & 114.873 .264 & $7.27 \%$ \\
Hollanda & 104.841 .136 & $6.64 \%$ \\
İspanya & 72.020 .982 & $4.56 \%$ \\
Fransa & 64.330 .030 & $4.07 \%$ \\
Birleşik Krallık & 53.322 .219 & $3.38 \%$ \\
Tayland & 52.436 .479 & $3.32 \%$ \\
Kanada & 36.076 .678 & $2.28 \%$ \\
Malezya & 30.120 .554 & $1.91 \%$ \\
Yunanistan & 29.891 .033 & $1.89 \%$ \\
Türkiye & 28.279 .675 & $1.79 \%$ \\
Almanya & 22.779 .972 & $1.44 \%$ \\
Birleşik Arap Emirlikleri & 22.142 .210 & $1.40 \%$ \\
\hline
\end{tabular}


Japonya'da 1997 yılında meydana gelen Nakhoda kazası, Fransa'da 1999 yılında meydana gelen Erika ve İspanya'da 2002 yılında meydana gelen Prestige gibi büyük çaplı kazalardan sonra petrol kirliliğinden kaynaklanan zararların tazmini edilmesi hususunda yeni arayışların ortaya çıkmasına sebebiyet vermiştir. Çevre hususunda sivil toplum örgütleri ve bu kazalardan etkilenen devletlerin ilgili İdareleri 1 Kasım 2003 tarihinde üst limitleri zaten arttırılmış olan 92 Sorumluluk Sözleşmesi ve 92 Fon Sözleşmesindeki üst limitlerin daha da arttırılmasını talep etmiş ve bu hususta daha radikal kararlar alınması önerilmiştir (Küçükyıldız, 2014). Örnek olarak çevre zararlarının tazminine ek olarak çevre zararlarının bilimsel metotlarla saptanması hususunda yapılan giderlerin de tazminat bağlamında değerlendirilmesi savunulmuştur (IOPC, 2003).

Uluslararası Denizcilik Örgütü (IMO) öncülüğünde 16 Mayıs 2003 tarihinde Londra'da gerçekleştirilen diplomatik Konferans'ta 1992 Fon Sözleşmesi'ne ilişkin olarak yeni bir Protokol (Supplementary Fund Protocol) kabul edilmiş ve bu bağlamda Petrol Kirliliği Ek Tazminat Fonu'nun (Supplementary Fund) tesis edilmesi kararlaştırılmıştır. Bu Protokol gereğince, Petrol Kirliliği Ek Tazminat Fonu'ndan tahsil edilebilecek tazminat miktarı, 1992 Sorumluluk ve Fon Sözleşmeleri bağlamında ödenecek meblağlar dâhil, 750 milyon Özel Çekme Hakkı (SDR) olarak öngörülmüştür (Abdullayev, 2003). Bu rakam 27 Ocak 2020 tarihi itibariyle 6.105.000.000 TL'ye tekabül etmektedir (IMF, 2020). Bu vesileyle EK Fon Protokolü'nün temel gayesi CLC 92 ve Fund 92 Sözleşmelerinin yetmediği yerde mağdurların tam ve zamanında tazminatlarının ödenmesini temin etmek ve böylece mezkûr sözleşmeleri tamamlamaktır. Bu bağlamda denilebilir ki Ek Fon, petrol kirliliğinin tazmini hususunda üçüncü kademeyi teşkil etmektedir ve 3 Mart 2005 tarihinde yürürlüğe girmiştir (Demir, 2012).

IOPC Fon verilerine göre 2020 y1lı itibariyle Ek Fon Protokolü'ne taraf devlet sayısı Türkiye dâhil 32'dir (IOPC, 2020).

1992 Fon Sözleşmesine paralel olarak Ek Fon’a yapılacak katkılar petrol ithal eden firmalar tarafindan bir önceki takvim yılında alınan petrol miktarı üzerinden hesaplanmaktadır. Bu hususta Protokol'e taraf olan devletler Fon'a her yıl 150.000 ton üzeri petrol ithal eden firmaların listesini bildirmekte ve bu firmalar da Fon tarafindan hesaplanan katkı miktarını ödemektedirler. 2019 yılı itibari ile 1992 Fon Sözleşmesine katkıda bulunan petrol alıcısı olan şahıs sayısı yaklaşık 440 civarıdır ve bunların yaklaşık 200 tanesi üçüncü kademe tazminat mekanizmasını teşkil eden Ek Fon'a katkıda bulunmaktadır (2018(b)).

Ayrıca belirtilmelidir ki; Ek Fon'a daha yüksek miktarda kaynak sağlayabilmek için Ek Fon Protokolü madde 14'te ifade edildiği üzere Protokole taraf her devlette yıllık minimum 1 milyon ton petrol ithal edildiği kabul edilmektedir. 1 milyon ton ile Fon'a sunulan miktar arasındaki katkı meblağının ödenmesi hususunda ilgili devlet sorumlu tutulmaktadır (2018(a)). Örneğin IOPC Fon'u 2018 yıllık raporuna bakıldığında Macaristan, Slovenya, Slovakya gibi devletlerde mukim petrol alıcıların toplam alım miktarı 1 milyon tona ulaşmadığından dolayı aradaki farkı bu ülke idarelerinin ödediği sonucuna ulaşılabilir (IOPC, 2018(b)). Öte yandan Ek Fon'a taraf bir devletin orantısız olarak büyük meblağlarda katkıda bulunmasını engellemek için Protokol madde 18/1'de bir sınırlandırma hükmü belirtilmiştir ve bu hükme göre tek bir akit devletin yapacağı yıllık katkı miktarı, akit devletler tarafından yapılan yıllık toplam katkı miktarının \% 20'sini geçemez (IOPC, 2018(a)). Eğer \% 20'yi geçer ise madde $18 / 2$ 'de belirtildiği gibi ilgili ülkedeki petrol ithal eden firmaların yaptığ 1 katkılar \% 20'ye ulaşıncaya kadar orantılı olarak düşürülür (IOPC, 2018(a)). Aşağıdaki Tablo 2'de görüleceği üzere Ek Fon'a en çok katkıda bulunan devlet yaklaşık \% 20'lik bir oran ile Japonya'dır ve Ek Fon'a katılım oranı arttıkça protokole taraf her bir devlettin yaptığı katkı oranı da kademeli olarak azalacaktır.

Tablo 2. Ek Fon'a Taraf Bazı Devletlerde 2017 Yılında Alınan Katk1 Petrolü*.

Table 2. Contributing Oil Received by Some Supplementary Fund Member States in 2017*

\begin{tabular}{lcc}
\hline Üye Devlet & 2017 Yılında Alınan Katkı Petrolü & Yüzde \% \\
\hline Japonya & 196.693 .667 & $19.85 \%$ \\
Güney Kore & 132.489 .698 & $13.37 \%$ \\
İtalya & 114.873 .264 & $11.59 \%$ \\
Hollanda & 104.841 .136 & $10.58 \%$ \\
İspanya & 72.020 .982 & $7.27 \%$ \\
Fransa & 64.330 .030 & $6.49 \%$ \\
Birleşik Krallık & 53.322 .219 & $5.38 \%$ \\
Kanada & 36.076 .678 & $3.64 \%$ \\
Yunanistan & 29.891 .033 & $3.02 \%$ \\
Türkiye & 28.279 .675 & $2.85 \%$ \\
Almanya & 22.779 .972 & $2.30 \%$ \\
İsveç & 21.539 .869 & 2.17 \\
\hline
\end{tabular}

(IOPC, 2018(b))*

3. Petrol Kirliliği Tazmininde Yeni Düzen: STOPIA ve TOPIA: Tablo 3 'den de görüleceği üzere petrol kirliliği tazmin sisteminde günümüzde geçerli olan CLC 92, FUND 92 ve Ek Fon Protokolü'nden müteşekkil 3 kademeli sisteme göre kirlilik mağdurları için 750 milyon SDR yani Özel Çekme Hakkı'na kadar tazminat miktarı sağlanabilmektedir. Fakat aşağıdaki Tablo 3'de açıkça görüldüğü üzere kirlilik mağdurların tazmininde gelinen noktada sorumluluk adil dağılmamaktadır ve makas petrol alıcı şirketleri aleyhine ciddi bir şekilde açılmıştır. Örneğin, tonaj olarak 5000 grostondan küçük bir tanker geminin maliki yol açtığ kirlilik sebebiyle maksimum 4.510 milyon SDR ile mesul tutulabilecek iken yol açtığı kirliliğin boyutuna göre petrol ithalatçıları tarafindan finanse edilen 92 Fonu 203 milyon SDR'ye kadar ve eğer ki tazminat miktarlarının bu meblağı aşması durumunda yine petrol 
alıcisi firmalar tarafindan finanse edilen Ek Fon 750 milyon SDR'ye kadar mesul tutulabilmektedir. Bu rakamlara gemi malikinin mesul tutulduğu miktarlar dâhildir. Her durumda bir geminin malikinin mesul tutulabileceği meblağ maksimum olarak yaklaşık 90 milyon SDR olmakta iken bu petrol alıcıları açısından 750 milyon SDR (buna tanker maliki mesuliyeti dâhil) olmaktadır.

Tablo 3. Petrol Kirliliği Tazmin Sisteminde Maksimum Tazmin Değerleri (Milyon SDR).

Table 3. Maximum Compensation Values in Oil Pollution Indemnification System (Million SDR)*

\begin{tabular}{lccc}
\hline Tanker GT & CLC92 (2003 sonras1) & Fon 92 (2003 sonras1) & 2003 Ek Fon \\
\hline 5.000 & 4.510 & 203 & 750 \\
10.000 & 7.665 & 203 & 750 \\
50.000 & 32.905 & 203 & 750 \\
100.000 & 64.455 & 203 & 750 \\
140.000 & 89.770 & 203 & 750 \\
250.000 & 89.770 & 203 & 750 \\
\hline (Kücükyıldı 2014)* & & &
\end{tabular}

Mesuliyetin paylaştırılması hususunda Ek Fon Protokolü ile aleyhine gelişen bu duruma binaen petrol alıcısı firmalar adına Petrol Şirketleri Uluslararası Denizcilik Forumu (OCIMF) tarafindan IMO'ya bir değerlendirme arz edilmiştir. $\mathrm{Bu}$ değerlendirmede OCIMF kirlilik tazminatı hususunda getirilen konvansiyonları ve Ek Fon'u desteklediğini fakat Ek Fon'u geçici bir çözüm şekli gördüğünü ifade etmektedir. Bu bağlamda konvansiyonlarda sınırlama hakkının yitirilmesi ve sorumluluk gibi hususlarda değişiklikler yapılması gerektiğini savunmaktadır. Öte yandan aynı süreçte Uluslararası P\&I Kulüpler Grubu (IG) gemi malikleri adına IMO'ya bir değerlendirme sunmuş ve mevcut sistemin başarı ile işlediğini ve devam eden sistemde herhangi bir oynamanın yapılmaması gerektiğini savunmuştur. Aslında bu mesuliyetin paylaştırılması hususu OCIMF ve IG tarafindan 2001-2003 yılları arasında Uluslararası Petrol Kirliliği Tazmin Fonu (IOPC) toplantılarında çetin bir çekişmeye sahne olmuştur. $\mathrm{Bu}$ süreçte OCIMF tarafindan savunulan argümanlar şöyledir:

a) Kirlilik konvansiyonlarının tasarladığ 1 sistem kazalarda herhangi bir payı olmayan petrol alıcılarının sağladığı katkılarla mağdurların finanse edilmesine dayalıdır. Zamanla makasın petrol alıcısı olan firmalar aleyhine açılması dengeyi bozmaktadir.

b) Denize dökülen petrol kaynaklı kirlenmeler tamamen gemi operasyonlarındaki kusurlardan kaynaklanmaktadir. $\mathrm{Bu}$ hususta operasyona herhangi bir dahli mevzubahis olmayan petrol alıcılarının mesul tutulmaları makul değildir.

c) Donatanın gemisinin düşük standartlı olmasından kaynaklanan kusurlardan petrol alıcılarının mesul tutulmaları makul değildir.

d) Amerikan Petrol Kirliliği Kanunu (OPA 90) yürürlüğe girdiğinden beri Amerika'da gemi kaynaklı petrol kirliliği \% 95 oranında azalma göstermiştir. Burada başarı OPA 90'nın öngördüğü kirleten ödesin temeline dayalı olan ve CLC 92'den daha sert bir mesuliyet rejimi öngören ve ayrıca donatanın mesuliyetini sinırlama limitlerinin daha yüksek olduğu bir konvansiyonun başarısıdır. $\mathrm{Bu}$ bağlamda CLC 92'nin öngördüğü mesuliyet rejiminde değişiklikler yapılmalı ve malikin mesuliyet limitleri arttırılmalıdır.

Uluslararası Koruma ve Tazminat Kulüpleri Grubu'nun (IG) savunduğu argümanlar ise;

a) CLC 69 ve Fon 71 konvansiyonlarında "kirleten ödesin” prensibi kabul edilmiş ve kirleten olarak petrol tankeri malikleri ve petrol alıcıları baz alınmıştır. Zira petrol alıcılarının kirlilikten sorumlu tutulmaları petrolün üretimi ve taşınması faaliyetinden çok ciddi kar elde etmesindendir. Malikin geliri olan navlun petrol pompa fiyatının yalnızca \% 8'ine denk gelmektedir ve bu bağlamda malikin kirlilik tazmini için tek adres gösterilmesi adil değildir.

b) 1990 ve 1999 yılları arası meydana gelen 360 tanker kazası incelendiğinde tazminatların eşit olarak paylaşıldığ 1 ve bu dengeyi bozmaya gerek olmadiğ belirtilmektedir.

c) Kirlilik konvansiyonlarında arzulanan amaç suçlunun cezalandırılmasından ziyade mağdurlar için etkili ve hızlı bir tazminat mekanizması teşkil etmektir. Bu bağlamda geminin kiracısı veyahut işleticisi gibi ayrımlara gidilmeden direk geminin kayıtlı maliki mesul tutulur ibaresi getirilmiştir. Buradaki gaye kusurun kiracıdan $\mathrm{m}$ işletenden mi vs. kaynaklandığının tespitinin uzun mahkeme süreçleri gerektireceğinden mağdurların tazmini hususunun uzaması mevzu bahistir. Bazen geminin malikinin petrol dökülmesi ile hiçbir alakası olmamasına rağmen sistem tarafından mesul tutulmuştur. Benzer olarak yük tarafina ait olan katkılar da tek bir petrol alıcısı firmadan toplanmamakta ve bunun yerine bütün alıcıların katkıda bulunduğu bir fondan yapılmaktadır.

$\mathrm{Bu}$ argümanlar 1șığında petrol kirliliğinin tazmininden mesul olan 2 taraf birbirlerine çeşitli uzlaşma teklifleri sunmuş ve nihai olarak OCIMF'in tezlerine yakın bir yerde uzlaşı sağlanmıştır. Bu bağlamda P\&I kulüpleri adına IG ile IOPC Fonları (1992 Fonu ve Ek Fon) arasında bir memorandum imzalanmış ve petrol kirliliği kaynaklı zararların paylaştırılması hususunda yeni bir düzenleme getiren bu düzenleme STOPIA 2006 (Small Tanker Oil Pollution Indemnification Agreement) ve TOPIA 2006 (Tanker Oil Pollution Indemnification Agreement) adlı iki ayrı sözleşmeye dayanmaktadır (Acar, 2007). Bu vesile ile 92 CLC'nin tadil edilmesi engellenmekle beraber gönüllülük esasına dayalı olarak tanker gemisi maliklerinin mesuliyet 
miktarları arttırılarak IOPC Fonlarının tazmin edilmesi amaçlanmaktadır (Küçükyıldız, 2014). IG üyesi P\&I kulüpleri memorandum gereği kendi üyeleri olan tanker maliklerinin bu iki sözleşmeye taraf olmasını sağlamayı yüklenmektedir.

Küçük tanker sahipleri arasındaki bir sözleşme olan STOPIA ile 29.548 GT'den küçük tonaja sahip olan tanker maliklerinin ödemesi gereken tazminat miktarını 20 milyon SDR'ye yaklaşık 27.500.000 dolara yükseltmektedir. Bu sözleşmenin Kloz III (B) kısmında belirtildiği üzere IG’ye üye herhangi bir P\&I kulübüne giren ve Havuz Sözleşmesi (Pooling Agreement) vesilesi ile reasüre edilen bütün küçük tanker malikleri bu mekanizmaya başvurabilecektir. Sözleşmenin Kloz III (B) kısmında belirtildiği üzere bu tankerler ilgili gemi (relevant ship) olarak ifade edilmekte ve ilgili gemilerin IG üyesi bir P\&I kulübüne girmekle STOPIA'ya otomatik girdiği kabul edilmektedir (IOPC, 2006). Özetle, 1992 Fonu STOPIA kapsamına giren gemilere ilişkin üçüncü tarafların tazmini hususunda sorumlu olmaya devam edecek fakat 29.548 GT'den küçük tankerlerin petrol kirliliğine yol açması durumunda mesuliyet limitleri olan 20 milyon SDR'ye kadar 92 Fonu tarafindan yapılacak olan ilave ödeme kulüp tarafindan sonradan Fona geri ödenecektir.

TOPIA'da STOPIA ile aynı esasa dayalıdır ve fark olarak TOPIA'da IG üyesi olan bir P\&I kulübüne girmiş olan ve Havuz Sözleşmesi mekanizması ile reasüre edilen bütün tanker malikleri başvurabilmektedir. TOPIA'da ilgili gemi hususunda herhangi bir grosston sinırlaması yoktur ve bu sözleşmeye göre katılan malik tanımlamasına uyan herhangi bir kimse Ek Fon'un petrol kirliliği zararının tazmini için ödediği miktarın \% 50'si sonradan Ek Fon'a geri ödenecektir.

2006 yılında gönüllülük esasına dayalı olarak devreye giren STOPIA ve TOPIA mekanizmalarının 10 yıl içinde meydana gelen kirlenme zararları 1șığında 2016 yılında gözden geçirilmesi ve bundan sonra da her beş yılda bir gözden geçirilmenin icra edilmesi öngörülmüştür. Burada sözleşmelerin Kloz VIII (C) kısmında belirtildiği üzere gemi malikleri ile petrol alıcısı firmalar tarafindan yapılan ödemelerin incelenmesi ve taraflardan herhangi birinin ödediği miktarın \% 60' 1 aştığının anlaşıldığı durumda bozulan eşitliğin temin edilmesi için gerekli önlemlerin alınması öngörülmüştür (IOPC, 2006).

\section{STOPIA 2006-TOPIA 2006 GÖZDEN} GEÇIRME VE DEĞERLENDIRME: IG, 1992 Fon'una STOPIA'ya giren tankerlerin listesini tedarik etmektedir ve bu bağlamda 2015 yılında STOPIA'ya giren tanker sayısı 6.485 iken bu rakam gözden geçirmenin yapıldığ 2016 yılı Ağustos ayında 6.180 'e düşmüştür. Ayrıca IG tarafından IOPC Fon'una yapılan bilgilendirmede IG kulüplerine giren ve STOPIA 2006'ya katılmayan ilgili gemi sayısı sıfir ve IG kulüpleri tarafından sigortalanıp STOPIA 2006'ya giren ve akabinde STOPIA 2006'dan çıkış yapan ilgili gemi sayısı da sıfır olmuştur. IG kulüplerine giren bazı tankerler STOPIA'ya girmemişlerdir zira bunlar Uluslararası Grup'un havuz anlaşmaları yoluyla reasüre edilmemektedirler. $\mathrm{Bu}$ kapsamda yer alan tanker sayıs1 2015 yılında 415 iken 20 Ağustos 2016 tarihi itibari ile 404'e düşmüştür. Öte yandan bu kategoride yer alan tankerler gemi malikleri ve P\&I kulüpleri arasında yapılan yazılı anlaşmaya göre ilgili gemi olarak düşünülebilir. Yazılı anlaşma ile STOPIA'ya giren tanker gemisi sayısı 2015 yılında 291 iken bu sayı 2016 yılı Ağustos ayında 282'ye düşmüştür. Örneğin 20 Ağustos 2016 tarihinin rakamları incelendiğinde görülmektedir ki 404 gemi IG üyesi P\&I kulüplerinden sigorta hizmeti almakta fakat IG havuz anlaşmalarında reasüre edilmemektedir. $\mathrm{Bu}$ 404 tankerin 282 tanesi bağımsız bir yazılı anlaşmaya dayalı olarak STOPIA kapsamına alınmıştır ve aradaki farka bakarsak 122 adet tanker belirtilen tarihte STOPIA mekanizmasına katılmamıştır. 20 Ağustos 2019 tarihine geldiğimizde STOPIA'ya giren gemi sayısı 6.339 tanesi ilgili gemi olarak ve 239 tanesi de yazılı anlaşmaya dayalı olmak üzere toplamda 6.578 olarak gerçekleşmiştir. Ayrıca IG kulüplerinden birine giren 29.548 ton ve aşağısındaki tonajdaki gemilerden 347 tanesi IG'nin havuz anlaşmalarına katılmamakta ve böylece STOPIA'ya otomatik olarak girmemektedir. Bunlardan 239 tanesi yazılı bir anlaşmaya dayalı olarak STOPIA'ya kapsamına alındığı için aradaki fark olan 108 gemi belirtilen tarih itibariyle STOPIA kapsamina girmeyen tanker sayısını vermektedir (IOPC, 2016(a); IOPC(c), 2019).

Tablo 4.'te görüldüğü üzere üzere IG, üyesi olan P\&I kulüplerinden sigorta hizmeti alan tankerlerin çok büyük bir kısmını giderek artan bir şekilde tesis ettiği STOPIA mekanizmasına soktuğu görülmektedir ve bu oran 20 Ağustos 2019 tarihi itibariyle \% 98.4'e ulaşmıştır. Burada IG'nin petrol kirliliğinin tazmini hususunda taraflar arasında mesuliyetin eşit paylaştırılması bağlamında etkili bir performans sergilemiştir.

Diğer tarafta IG üyesi bir P\&I kulübüne girmekle beraber IG'nin havuz anlaşması yoluyla reasüre edilmeyen ve böylece STOPIA mekanizmasına katılmayan belli bir sayıda tanker gemisi mevcuttur. Tablo 5.'te de görüleceği üzere bunların ciddi bir kısmının IOPC Fonu'na en çok katkıda bulunan ülkelerden bir olan Japonya'daki koster tanker filosundan kaynaklandığı görülmektedir. Japon koster tanker gemileri analiz edildiğinde görülmektedir ki Japon P\&I Kulübüne Giren 200 grosston üzeri tanker maliklerinin hemen hemen hepsi (\% 99) havuz anlaşmaları yoluyla reasüre edilmekte ve STOPIA mekanizmasına katılım sağlamakta iken Japon P\&I kulübüne giren toplam Japon koster tanker gemi sayısı incelendiğinde bu oran \% 65 'lere düşmektedir. Burada açıkça görülmektedir ki 2011 ve 2012 yılları baz alındığında 200 GT'dan küçük olan ortalama 170 Japon koster tanker gemisi IG üyesi olan Japan P\&I 
Kulübünden sigorta hizmeti almasına rağmen kulübün de tarafı olduğu havuz anlaşmalarına katılmamakta ve böylece STOPIA'ya dahil olmamaktadır. Günümüzde de IG üyesi bir kulüpten sigorta hizmeti tedarik etmekte olup mezkûr mekanizmaya dâhil olmayan filonun çoğunun buradan geldiği düşünülmektedir.

Tablo 4. STOPIA 2006'ya katılım oranları.

Table 4. Participating Ratios to STOPIA 2006

\begin{tabular}{|c|c|c|c|c|}
\hline Y11 & $\begin{array}{l}\text { STOPIA'ya giren tanker sayısı (İlgili gemi ve } \\
\text { yazılı anlaşma ile katılan gemilerin toplamı) }\end{array}$ & $\begin{array}{l}\text { IG kulüpleri tarafindan sigortalanan fakat } \\
\text { STOPIA'ya girmeyen tanker sayısı }\end{array}$ & Toplam & $\begin{array}{l}\text { STOPIA'ya giren toplam yüzde } \\
\qquad(\%)\end{array}$ \\
\hline 20.02 .2011 & 6.173 & 208 & 6.381 & 96.7 \\
\hline 20.08.2011 & 6.317 & 174 & 6.491 & 97.2 \\
\hline 20.02.2012 & 6.039 & 164 & 6.203 & 97.4 \\
\hline 15.08 .2015 & 6.776 & 124 & 6.900 & 98.2 \\
\hline 20.08.2016 & 6.462 & 122 & 6.584 & 98.1 \\
\hline 20.08.2018 & 6.758 & 116 & 6.874 & 98.3 \\
\hline 20.08 .2019 & 6.578 & 108 & 6.686 & 98.4 \\
\hline
\end{tabular}

Tablo 5. Japon Koster Filosu STOPIA Penetrasyon Oranları*

Table 5. Japanese Coastal Fleet STOPIA Penetration Ratios*

\begin{tabular}{lccc}
\hline Y11 & Japon P\&I Kulübüne Giren Japon Koster Tanker Gemi Sayıs1 & STOPIA'ya Giren Gemi Sayısı & STOPIA'ya Girme Yüzdesi (\%) \\
\hline 20.02 .2011 & 506 & 331 & 65 \\
20.08 .2011 & 501 & 327 & 65 \\
20.02 .2012 & 478 & 314 & 66 \\
\hline \multirow{2}{*}{ Y11 } & Japon P\&I Kulübüne Giren 200 GT Üzeri Japon Koster & \multirow{2}{*}{ STOPIA'ya Giren Gemi Sayıs1 } & \multirow{2}{*}{ STOPIA'ya Girme Yüzdesi(\%) } \\
\hline 20.02 .2011 & Tanker Gemi Sayıs1 & 143 & 99 \\
20.08 .2011 & 144 & 139 & 99 \\
20.02 .2012 & 141 & 143 & 99 \\
\hline
\end{tabular}

(IOPC Fon raporlar1)*

IG tarafindan Ek Fon'a yapılan raporlamada ifade edildiği üzere, 2016 yılı rakamlarına göre IG üyesi bir kulübe giren ve TOPIA'ya girmeyen ilgili gemi sayısı sıfırdır. IG kulüpleri tarafından sigortalanırken TOPIA mekanizmasına giren ve sonradan TOPIA'da yer almaktan vazgeçen ilgili gemi sayısı da sıfırdır. Ayrıca IG tarafından Ek Fon'a yapılan raporlamada yer aldığı üzere herhangi bir IG üyesi kulübe giren tankerlerden STOPIA 2006'ya yazılı anlaşma ile girmiş olan gemiler (282 adet) TOPIA 2006'ya girmemişlerdir. Çünkü bu koster tankerlerin kapasitesi çok küçüktür ve böyle tankerlerden kirlilik hasarı sonrası oluşan hasar tazminat talep maliyetlerinin 1992 Fon Sözleşmesi limitlerini (203 milyon SDR) aşması ihtimal dışı olarak düşünülmektedir. Ayrıca belirtilmelidir ki IG'nin tesis ettiği havuz anlaşmalarına girmediği için TOPIA 2006'ya girmeyen tanker sayısı 404'dür. 2019 Ekim itibariyle IG kulüplerinden sigortalandığı halde IG havuz anlaşmalarına katılmayan gemi sayısı 347'ye düşmüştür ve bunların 239 tanesi yazılı anlaşmaya istinaden STOPIA'ya girmişlerdir fakat yukarıda belirtilen sebebe binaen TOPIA'ya girmemişlerdir. Her ne kadar bu ufak tonajlı gemilerin Fon 92 limitlerini aşmayacağ düşünülse de teoride bu gemilerden herhangi birinin lüks bir otele, restoranta, denizde üretim yapan balık çiftlikleri bölgesine, lüks yatlara, balıkçı ağlarına vs. verebileceği zararların toplamının Fon 92 limitlerini aşması ihtimal dâhilindedir ve bir risk unsuru taşıdığı aşikârdır. $\mathrm{Bu}$ bağlamda IG'nin STOPIA bağlamında gösterdiği etkinliğin bir benzerinin TOPIA hususunda da gösterilmesi beklenmektedir.

IOPC Fon'u bu iki sözleşmeye taraf değildir ve bu sözleşmelere yapılacak herhangi bir düzenleme için IOPC Fon'unun rızasının alınmasına gerek yoktur. Öte yandan gözden geçirme süresince IOPC Fon sekretaryası tarafından yapılan yorumların IG dokümanlarında geniş bir şekilde yansitılmasına binaen Fon direktörü, gözden geçirme sonuçlarını ve önerilen düzeltmeleri uygun bulmuştur (IOPC, 2016(a)).

Her ne kadar 1992 Fonu bu iki sözleşmeye taraf olmasa da sözleşmelere uygun olarak gemi maliklerinden tazminat elde etme hususunda yasal hakka haizdir. IOPC Fon'u 2018 yıllık raporuna göre şu ana kadar STOPIA altında 1992 Fonu'na Solar 1 (Filipinler, 2006) kazası hususunda ödeme yapmıştır ve ayrıca STOPIA'nın Trident Star (Malezya, 2014) kazasına da uygulanabileceği belirtilmektedir. OCIMF 2018 yıllık raporunda Double Joy (Malezya, 2014) kazası sonucu oluşan tazminat bedelinin CLC 92 limitlerini aşarak 92 Fon'unun devreye girebileceğini yani STOPIA'nın uygulanabileceği belirtse de IOPC Fon'u 2018 yıllık raporunda, bütün hasar tazminat taleplerinin gemi maliki/sigortacısı ile anlaşmaya varılarak çözüme kavuşturulduğu ve buradaki meblağın CLC 92 limitleri içerisinde olduğu ve IOPC Fon'unun devreye girmesine gerek kalmadığı belirtilmiştir (IOPC, 2018b; OCIMF, 2018). 
Ek Fon'un dâhil olduğu herhangi bir kaza şu ana kadar meydana gelmediği için TOPIA 2006 mekanizması şu ana kadar henüz uygulanmamıştır. Ek Fon'un tazminat ödemesi gereken her bir kaza için bir Hasar Tazminat Fonu (A Claim Fund) kurulur ve şu ana kadar Ek Fon'un dâhil olduğu herhangi bir kaza meydana gelmediği için herhangi bir Hasar Tazminat Fonu kurulmamıştır (IOPC, 2018). Öte yandan Ek Fon'a taraf bir ülkede meydana gelen ilk kaza 2012 yılında Yunanistan'da meydana gelen Alfa I kazasıdır fakat bu kaza sonucu hâsıl olması beklenen tazminat talep miktarının 92 Fon limitini aşması ihtimal dışı olarak görülmektedir. 1992 Fon'un da dosyası kapatılmayan bir vaka olarak duran Alfa I kazasında, Yunanistan bayraklı tanker gemisinin malikinin sabit prim P\&I kulübü olan Aigaion Sigorta Şirketi, malikin sigortacısı olarak sunduğu kirlilik sigortası teminat kapsamının herhangi bir kaza için toplam hasar tazminat talebinin gemi başına 2 milyon Avro ve poliçe şartlarında açıkça belirtildiği üzere teminatın kalıcı olmayan kargolar (non-persistent) için geçerli olduğu argümanlarına binaen malikin CLC 92 bağlamında bulunan 4,51 milyon SDR'ye denk gelen mesuliyetini kabul etmemektedir. Öte yandan malikin gemisi için CLC sertifikası düzenleyen Yunanistan'ın Pire Merkez Liman İdaresi, sigorta şirketi tarafindan kendilerine sunulan mavi kartın, sigorta poliçesinin CLC 92 madde 7'ye atıf yaparak sözleşmenin uygulanabileceği mekân ve zaman (where and when applicable) hükmüne uyduğunu tedarik ettiğini ifade etmektedir. Yunan idareleri tarafindan bu sigorta poliçesindeki teminat kapsamı ve liman idaresine sunulan mavi karttaki teminat kapsamındaki uyuşmazlık için ayrıca soruşturma açılmıştır. 1992 Fon'unun hukuk danışmanının görüşlerine göre sigortanın mesuliyeti teminat kapsamı ve sertifikadaki açık çelişkiye bakılmaksızın oluşmaktadır ve sigortacının, teminatın ihlali iddiasına binaen herhangi bir hasar tazminat talebini reddetmemelidir (IOPC, 2012) . Bu vaka, zorunlu sigorta konusunun ne kadar ihmale gelmeyecek mühim bir mesele olduğunu göstermesi ve liman idarelerine dikkate almaları gereken bir husus olduğunu açık bir şekilde göstermektedir. Bu bağlamda Yunanistan'daki liman idarelerine örnek olması açısından belirtilmelidir ki Ulaştırma ve Altyapı Bakanlığı, Türkiye Cumhuriyeti limanlarına giriş yapacak tankerlerin petrol kirliliği teminatı hususunda sahip olabileceği P\&I kulüplerinin listesini her y1l güncelleyerek Muteber P\&I kulüpleri olarak sitesinden deklare etmekte ve bunların büyük çoğunluğunu IG kulüpleri teşkil etmektedir.

IG, STOPIA ve TOPIA mekanizmalarının 2006 yılında devreye girmesinden sonraki 10 yıllık periyodu gözden geçirmiştir ve bu bağlamda bu sözleşmelere ufak düzeltmeler yapmıştır (Oil spills India, 2018). Her iki anlaşma 20 Şubat 2006 ve 20 Şubat 2016 arası geçen 10 yıllık periyot için CLC 92, IOPC Fon'u ve Ek Fon hasar tazminat talepleri verisi için benzer gözden geçirme klozları ihtiva etmektedir. IG bu gözden geçirmeyi IOPC Fon Sekreteryası ve petrol alıcıları adına OCIMF ile beraber 2016 yılı başında başlamıştır. Gözden geçirme sonucu bu 10 yillık periyotta gemi malikleri tarafindan ödenen hasar tazminat taleplerinin toplam maliyetinin petrol alıcılarının ödediğinden çok daha fazla olduğu vurgulanmıştır. Her iki sözleşme de herhangi bir eşitsizliğin hâsıl olması durumunda finansal mesuliyetin dengelenmesi hususunda klozlar ihtiva etmektedir.

10 yıllık gözden geçirme periyodu verilerine göre gemi maliklerinin/IG kulüplerinin dâhil olduğu vaka sayısı 348 ve IG kulüp üyesi tanker maliklerinin ödediği toplam maliyet 256.810.499 dolardır. Öte yandan IOPC Fon'unun dâhil olduğu vaka sayısı 2 ve maruz kaldığı toplam maliyet 41.777.445 dolardır. Bu bağlamda denilebilir ki yapılan ödemelerin \% 86'sı IG kulüp üyesi tanker malikleri tarafından \% 14'ü ise 1992 IOPC Fon'u tarafindan üstlenilmiştir. Aradaki farkın bu kadar keskin olması IOPC Fon'unun genellikle büyük çaplı kazalarda devreye girmesinden ve malik mesuliyetinin aşan kısmından sonra devreye girmesinden kaynaklanmasidır. Ayrıca bu rakamlar sadece gözden geçirme periyodu için ödenen meblağı göstermektedir ve bu periyotta vaki olup da ödenmemiş tazminatların da olması muhtemeldir. $\mathrm{Bu}$ rakamlar IG kulüp harici kulüplerden kirlilik teminatı alan gemi maliklerini hesaba katmamaktadır (IOPC, 2016b). Sözleşmelerin Kloz VIII (C) kısmında belirtildiği üzere gemi malikleri ile petrol alıcısı firmalar tarafindan yapılan ödemelerin incelenmesi ve taraflardan herhangi birinin ödediği miktarın \% 60’’ aştığının anlaşıldı ̆̆ bozulan eşitliğin temin edilmesi için gerekli önlemlerin alınması öngörülmüştür. Öte yandan Uluslararası Deniz Ticaret Odası (ICC) ve Uluslararası Bağımsız Tanker Sahipleri Derneği'ne (INTERTANKO) danışma sonucu IG, finansal mesuliyetin dengelenmesi ile ilgili Kloz VIII (C) hususunda herhangi bir önlemin icra edilmemesine karar vermiştir. IG, Heberei Spirit vakasında bu 10 yıllık dönem boyunca bir araya getirilen verilerin IOPC Fon'u tarafindan yapılan toplam ödemeleri tam olarak yansıtmadığını ve IOPC Fon'u tarafindan dosyası kapatılmayan bu vakanın gelecek 10 yıllık gözden geçirmede yer alacağını belirtmiştir. Bu vaka için beklenen ödemeler dikkate alındığında yükün eşit bir şekilde dağıldığının görüleceği ifade edilmektedir. Öte yandan IG gelecekte herhangi bir aleyhine eşitsizliğin oluşması durumuna binaen sözleşmeler üzerinde gerekli değişikliği yapma hakkını saklı tutmaktadır (Britannia, 2017).

STOPIA ve TOPIA sözleşmelerine 10 yıllık gözden geçirme sonucu bazı değişiklikler yapılmıştır ve bundan böyle STOPIA 2006 (2017 düzeltilmiş hali) ve TOPIA 2006 (2017 düzeltilmiş hali) olarak yeniden adlandırılmıştır.

Burada yapılan değişiklikler şunlardır: 
- Gelecek gözden geçirmelerin 5 yıllık hasar tazminat talep verisi (claim data) yerine orijinal sözleşmede ilk gözden geçirme için geçerli olan 10 yıllık bir süreç için yapılmas 1 kararlaştırılmıştır ve bu bağlamda gelecek gözden geçirme 2026 yllında icra edilecektir. Zira IG'ye göre 5 yıllık periyotlarla yapılacak gözden geçirmelerde taraflar arasında mesuliyetlerin paylaştırılması ile alakalı olarak herhangi anlamlı bir sonuca ulaşmanın zor olduğu ve sürenin çok kısa olduğu belirtilmiştir.

- Gelecek gözden geçirmede o dönemin hasar tazminat talep verisinin yerine bütün gözden geçirme periyotlarında toplanan kümülatif hasar tazminat talep verilerinin dikkate alınması kararlaştırılmıştır.

- Gemi maliklerini ve sigortacılarını herhangi bir uygulanabilir yaptırım rejimi kapsamına giren bir ödeme yapılmasını engelleyen bir yasamanın sonucu olarak, gemi maliklerini ve IG kulüplerini, kontrolleri dışındaki sebeplerin geliştiği durumlar karşısında, sözleşmelere uygun olarak 1992 Fonu'na ve Ek Fon'a geri ödeme yapmasını önleme hususunda korumak için güncellenen sözleşmenin IV (H) kısmına ilgili hükümler eklenmiştir (Britannia, 2017). Zira deniz ulaştırması, ticareti ve ilintili olarak sigorta ve reasürans aktiviteleri üzerindeki uluslararası yaptırımlar ve engellemeler IG kulüplerinin ve daha geniş kapsamda sigorta endüstrisinin sigorta teminatı ve kuralları üzerinde sona erme/fesih klozlarını (cesser clause/ termination clause) devreye sokması ile sonuçlanmaktadır. Sigortalı tarafin yaptırımı delen sefer yapması durumuna binaen IG kulüplerinin ve reasürörlerinin korunması için bu önlemler gereklidir. Avrupa Birliği veyahut $\mathrm{ABD}$ yaptırımlarının ihlali birçok açıdan maddi bazen de hapis gibi cezalandırmalara sebebiyet verebilmektedir.

\section{SONUÇ}

Tanker gemilerinin sebep olduğu petrol kirliliğgi tazminat rejiminin ilk ayağı CLC 1969 ve Fon 1971 Sözleşmeleri ile teşkil edilmiştir. Daha sonradan tanker malikinin ve IOPC Fonu'nun mesuliyet miktarların arttıran CLC 1992 ve Fon 1992 Konvansiyonları ile tadil edilen bu iki basamaklı tazminat sistemine, kaza kaynaklı tazminat miktarlarının artmasına binaen 2005 yılında devreye giren Ek Fon Protokolü 2003 getirilerek böylece üç basamaklı tazminat sistemi oluşturulmuştur. Ek Fon, CLC 92 ve Fon 92 Sözleşmelerine binaen hala tazmin edilmeyen meblağlar mevcut ise aradaki farkı kapatmak için devreye girmekte ve günümüz rakamlarıyla yaklaşık olarak 6.100.000.000 TL'ye kadar teminat sunabilmektedir. Bu çapta yüksek teminat sunabilen Ek Fon'un finansman yükünün petrol alıcıları tarafından üstlenilmesi beraberinde tartışmaları da getirmiştir. $\mathrm{Bu}$ bağlamda petrol alıcılarının yüklendiği mesuliyetin dengelenmesi hususunda 13 büyük $P \& I$ kulübünü bünyesinde barındıran Uluslararası P\&I Kulüpler Grubu, STOPIA ve TOPIA adlı iki mekanizmayı devreye sokarak tanker malikleri adına mesuliyetlerin taraflar arasında eşit bir şekilde dağııılmasını hedeflemiştir. Bu mekanizmalarla CLC 92 ile sorumluluğu sinırlandırılan tanker maliklerinin mesuliyet miktarları arttırılarak IOPC Fon'larını tazmin etmesi sağlanmıştır. Uluslararası Grup'un, üyesi olan P\&I kulüplerinden sigorta hizmeti alan tankerlerin çok büyük bir kısmını tesis ettiği STOPIA mekanizmasına soktuğu görülmektedir. Burada Uluslararası Grup'un petrol kirliliğinin tazmini hususunda taraflar arasında mesuliyetin eşit paylaştııılması bağlamında etkili bir rol oynamıştır. $\mathrm{Bu}$ çaba sözleşmelerin yeniden tadil edilmesi tartışmalarının önünü kesmiştir fakat denebilir ki petrol kirliliğin tazminine dair CLC 92, Fon 92, Ek Fon Protokolü, STOPIA ve TOPIA gibi düzenlemeler çok parçalı bir görüntü sergilemektedir ve yeknesak bir mesuliyet rejiminin getirilmesi uygulamada kolaylık sağlayacaktır. Ayrıca Uluslararası Grup'un konu hususunda oluşturduğu mekanizmalarına girmeyen az sayıda tankerin tazminat rejiminde dengenin sağlanması hususunda risk unsuru ihtiva etmeye devam etmektedir ve bu bağlamda Uluslararası Grup'un STOPIA hususunda gösterdiği etkinliğin bir benzerini TOPIA hususunda da göstermesi beklenmektedir.

\section{KAYNAKLAR}

Abdullayev, C. (2003). Uluslararası Hukuk Açısından Denizyolu Ille Tașımacıllktan Kaynaklanan Petrol Kirliliği, T. C. Ankara Üniversitesi Sosyal Bilimler Enstitüsü Kamu Hukuku Anabilim Dalı, Çankaya-Ankara, Türkiye, 393s.

Acar, S.(2009). Petrolden kaynaklanan kirlenme zararlarının tazmininde yeni Dönem: STOPIA ve TOPIA. e-akademi; Hukuk, Ekonomi ve Siyasal Bilimler Ayllk Internet Dergisi, 83, 42s. (*).

Acar, S. (2007). Kulüp sigortası (P\&I), T.C. İstanbul Üniversitesi, Sosyal Bilimler Enstitüsü, Özel Hukuk Anabilim Dalı, İstanbul-Türkiye, 638 p.

Billah, M.M. (2011). The Role of Insurance in Providing Adequate Compensation and in Reducing Pollution Incidents: the Case of the International Oil Pollution Liability Regime, Pace Environmental Law Review (29)I, 78 p. 
Demir, İ. (2012). 1992 Petrol Kirliliği Zararının Tazmini İçin Bir Uluslararası Fonun Kurulması İle İlgili Uluslararası Sözleşme'de 2003 Tarihli Protokol İle Kabul Edilen Değişiklikler. İnönü Üniversitesi Hukuk Fakültesi Dergisi, 3(1), 213-256.

Küçükyıldız, M.Ç (2014). Petrol Tankeri Kazalarının Deniz Çevresine Etkileri Ve Tazmin Sistemi, T.C Ulaştırma, Denizcilik Ve Haberleşme Bakanlığı. Çankaya-Ankara, Türkiye, 100s.

Keçeli, A., Pekşen, N.H. \& Küçükyıldız, M.Ç. (2016). Petrol kirliliği hukuki sorumluluğu ve uluslararasi tazmin sistemi \& ulusal mevzuat, 1992 uluslararası petrol kirliliği tazmin fonu talepler el kitabı Ekim 2013 baskısı gayriresmi tercümesi \& ilgili mevzuat ve uygulamalar. T.C Ulaştırma, Denizcilik Ve Haberleşme Bakanlığı. Çankaya-Ankara, $41 \mathrm{~s}$.

IOPC. (2003). The IOPC Funds' 25 Years of Compensating Victims of Oil Pollution Incidents, London, $118 \mathrm{p}$.

IMF. (2020). https://www.imf.org/external/np/fin/data/ rms_sdrv.aspx

IOPC. (2018 a). Liability and compensation for oil pollution damage, Texts of the 1992 Civil Liability Convention, the 1992 Fund Convention and the Supplementary Fund Protocol, London, $30 \mathrm{P}$.

IOPC. (2018 b). https://iopcfunds.org/wpcontent/uploads/2019/03/Annual-Report_2018for-WEB_e..pdf Annual report, London, 56 p.

IOPC Funds. (2020). https://iopcfunds.org/aboutus/membership/a-z-listing/

OCIMF. (2018). Annual report, 5p. https://www.ocimf.org/media/86798/ocimfannual-report-2018-web-.pdf

OIL SPILLS INDIA. (2018). Conventions, claims \&compensation, developments \& Industry perspectives: The 2003 supplementary fund protocol and stopia/topia: an IG perspective, Oil Spill India 5\&6 July, 2018, India.

The Britannia Steam Ship Insurance Association Limited (2017). STOPIA 2006 and TOPIA 2006 - review and amendments for 2017, Circular, 23p.

IOPC Funds. (2006). Small Tanker Oil Pollution Indemnification Agreement Stopia 2006, STOPIA 2006 and TOPIA 2006, London, 29p.

IOPC Funds. (2016 a). Recent information on entered ships and revision of STOPIA 2006 and TOPIA 2006, London

IOPC Funds. (2016 b). Agenda Item 4, Submitted by the International Group of P\&I Associations, STOPIA 2006 and TOPIA 2006, London, 4 p.
IOPC Funds. (2016 c). Agenda Item 11, Record Of Decisions Of The October 2016 Sessions of The Iopc Funds' Governıng Bodies, London, 89 p.

IOPC Funds. (2011). International Convention on Civil Liability for Oil Pollution Damage, 1992, Texts of The 1992 Civil Liability Convention, the 1992 Fund Convention and the Supplementary Fund Protocol, Liability and Compensation for Oil Pollution Damage, London, 58 p.

IOPC Funds. (2012). Incidents, https://iopcfunds.org/incidents/incidentmap/\#1912-05-March-2012

IOPC Funds. (2019). Recent Information on Entered Ships, IOPC/OCT19/4/2, https://documentservices.iopcfunds.org/meetingdocuments?filter-year=2019 